\title{
Transforming cost design into environmentally conscious cost design in Japan: likelihood and problems for further development
}

\author{
Akira Nishimura
}

Published online: 13 August 2014

(C) The Author(s) 2014. This article is published with open access at Springerlink.com

\begin{abstract}
The purpose of this paper is to clarify the process by which cost design in Japan becomes environmentally conscious cost design and to consider the possibility of its further development and generalization. We first define cost design as proactive manufacturing of low cost and high quality at the design stage, in contrast to the standard cost system, and inquire into the extension of this process to the global supply chain and product life cycle. Second, we recognize the development of environmentally conscious cost design as a result of the integration of supply chain costing and life cycle assessment into cost design from the viewpoint of environmental management. Third, we use corporate social and environmental reports in the Japanese transport equipment and electric machine industries to investigate the state of environmentally conscious products, environmentally conscious design, eco-procurement, and life cycle assessment. To conclude, we make several proposals for further development of environmentally conscious cost design after analyzing the likelihood of success and some obstacles.
\end{abstract}

Keywords Cost design - Global supply chain - Product life cycle · Design for environment · Environmentally conscious cost design

\section{Introduction}

Global warming and changing ecological systems have led to increased environmental consciousness among enterprises and consumers. In particular, enterprises that participate in material exploitation, processing, distribution and disposal may not be viewed favorably by stockholders, employees, and consumers unless those enterprisesprovide

\footnotetext{
A. Nishimura $(\varangle)$

Faculty of International Business Management, Beppu University, 7-18-8, Miwadai, Higashi,

Fukuoka, Japan

e-mail: akiran@nm.beppu-u.ac.jp; ZTD03361@nifty.com
} 
environmentally friendly products. Because of this, environmental management has become an important part of enterprise strategic management. Recently, there have been many studies on environmentally conscious manufacturing (ECM), the recovery and reuse of materials and products, and waste and pollution control (Gungor and Gupta 1999; Henri and Joumeault 2010; Ilgin and Gupta 2010; Pondeville et al. 2013). However, a great deal of research on environmental costing and environmental cost management remains to be done.

Enterprises should make efforts to reduce their environmental impact even as they try to balance these efforts with profitability efforts. These enterprises should therefore establish a model that integrates environmental costs into their cost management strategy while maintaining profitability. Toward this end, some study of environmental costing and environmental cost management has been conducted (Kreuze and Newell 1994; Parker 2000; Steen 2005; Ito 2006; Hunkeler et al. 2008; Horváth and Berlin 2012; Gabriel et al. 2014). In regard to this subject of study, Horváth and Berlin (2012) in particular offer insight on integrating the costs of environmental requirements with target costing ${ }^{1}$ and take a proactive view of 'green target costing'. They also divide green target costing activities into six steps, such as the evaluation of target selling price including green price premium and green kaizen (continuous improvement) costing, mirroring the six principles of target costing: price-led costing, focus on customers, focus on design, cross-functional involvement, life cycle orientation, and value-chain involvement. As a result, a comprehensive product design approach is built, in which environmental costs and impacts are identified and improved by incorporating them into the steps, and customers' requirements can be met along with environmental requirements and cost constraints together with product design. Their views motivate this study of environmentally conscious cost design.

In Japan, researchers have only just begun to examine the integration of environmental consciousness with cost management, although some large companies are said to have developed environmentally conscious management to gain a competitive advantage or better utilize limited natural resources (Sarkis 1995). Ito (2007) and METI (2002) threw a comprehensive light on the subject of environmentally conscious cost design (ECCD) and its status as a new stage of cost design in their investigation, the results of which were published as A Workbook for Environmental Management Accounting by the Japanese Ministry of Economy, Trade and Industry (METI) (also see Ito 2006). Kajihara et al. (2009) also conducted a factual survey on design for environment and cost design in the general machine, electrical machine, transportation equipment, and precision machine industries in Japan. They found that $79.2 \%$ of firms had implemented design for environment, $73.1 \%$ had implemented cost design, and $59.7 \%$ of firms had implemented both (see Park 2007, 2009). Although these studies suggest the possibility of evolving conventional cost design into a comprehen-

\footnotetext{
1 Although cost design in Japan is expressed as target costing in other countries, this paper uses 'cost design' to focus on its main characteristic_-proactive cost management, or 'proactively manufacturing cost and quality into a product' (tsukurikomi in Japanese)—from the standpoint of profitability rather than of costing. The distinction between cost design and target costing and its effects needs further discussion. Ito (2006) also points out that cost design is by no means a kind of costing, but is instead cost management to proactively manufacture "the conditions of cost occurrence."
} 
sive environmental cost design, a relation between design for environment (DFE) and ECCD, as well as a concrete procedure for carrying out this cost design, remains a subject of debate, as these studies have clarified neither the relation between DFE and life cycle costing and eco-procurement nor the difference between DFE and ECCD.

The purpose of this paper is to clarify the relation between environmental management and cost design and describe the current state of ECCD. Some remaining problems whose solution will advance ECCD are also described. Our analysis depends primarily on the social and environment reports of companies listed on the Tokyo Stock Exchange in the electric machine and transportation equipment industries. This is because these companies have long histories of implementing cost design [82.5\% in the electric machine industry (2002 data), $76.5 \%$ in the transportation equipment industry (2002 data), and $81.5 \%$ in the manufacturing industry (2009 data)] and are more likely to evolve cost design into ECCD (Yoshida et al. 2012; JAMS 2005, 2009).

We must first define the concept of cost design to understand how it can become ECCD. We therefore begin by comparing cost design with standard costing practices and explain the fundamental characteristics of cost design. In Sect. 3, we will discuss product life cycle, environmental management, and the extension of cost design to global supply chains and the complete life cycle. In Sect. 4, we analyze the relation between cost design and environmental consciousness, investigate the actual state of ECCD, and list some of the problems that should be addressed for the further development and generalization of ECCD. To conclude, we examine a fundamental framework for ECCD to allow both high value (high function at low cost) and minimal environmental impact from a socioeconomic angle. This paper aims to clarify the present state of Japanese green cost design and its structure and meanings. In clarifying, the implication of comprehensive cost management, upon which Horváth and Berlin (2012) touched in relation to the absorption of environmental awareness into target costing, should be kept in mind, and inquiry into further development and problems of environmentally friendly cost design in Japan will adopt the socioeconomic viewpoint in this study.

\section{Cost design and its space-time expansion}

\subsection{Comparison of cost design with the standard cost system}

Cost design was energetically discussed in the Japanese academic literature of the 1990s. Because it has been discussed from multiple angles, including costing, cost management (cost planning and control), cost engineering, and profit management, there is not yet a universal definition of the term (IMA 1994; Sato 2009). However, here we should define cost design before launching a discussion of ECCD since the recognition of ECCD is influenced by the understanding of cost design.

Monden and Hamada (1991) first used the management practices of Toyota Motor Corporation to define cost design as proactive cost reduction at the design $\operatorname{stage}^{2}$ of a

\footnotetext{
2 'Design stage' in this paper is used in a broad sense that includes conception, planning, development and design, trial manufacture, and preparation for production.
} 
new product, contrasting this with reactive cost reduction at the manufacturing stage (see Monden and Hamada 1991; Monden 1999): that is, cost reduction by using the standard cost system. In connection with this issue, Tanaka (1992) used the following equation to compute target costs and clarify the difference between cost design and standard costing, or budget control (see Tanaka 1992, 1993; Sakurai 1989, 1991).

This equation is $g=(S p-C t) Q v-(S p-C e) Q v=(C e-C t) Q v$, where $g$ is cost variance, $S p$ is the target selling price, $Q v$ is the target sales volume, $C t$ is the target cost, and $\mathrm{Ce}$ is the estimated cost.

In this equation, it is most important to minimize cost variance by means of proactive kaizen and innovation, which help to achieve target costs. These are especially important when the target cost is lower than the estimated cost. In such cases, the category of product value, which motivates the above equation, is understood as the ratio of function to cost and becomes an effective index to improve product function with minimum cost. This proactive control view, which is based on exhaustive value engineering, is fundamentally different from the reactive view of standard costing, in which actual cost is evaluated on the basis of standard cost as the true cost. Thus, the proactive view analyzes variance and enacts the remedial measures for that before production to realize target cost, and the reactive view controls in the next period by ex post fitting to the standard cost of the previous period. In seeking to explain the concept of value in cost design, Tani $(1994,1995)$ also noted the engineering aspects of proactive cost management, including simultaneous engineering, concurrent engineering, and cooperation with suppliers (see Tani et al. 1994; Yoshikawa 1994). Tanaka (1985) stressed design-stage value engineering, using a cost table ${ }^{3}$ for feed forward cost estimation. Cost design that is founded on these engineering methods and includes cost management can be regarded as total profit management in the whole organization of a company (see Kato 1993a, b; Kato et al. 1995; Tanaka 1985, 1995, 2002; JAMS 2009).

Table 1 shows the fundamental features of cost design as discussed in the literature above and compares those features with those of the standard cost system ${ }^{4}$.

On the basis of the contents of Table 1, this paper defines cost design as cost management to proactively manufacture new value (high function at low cost) into a product at the design stage to gain a competitive advantage. This idea is called tsukurikomi in Japanese and can be translated as "built-in cost and quality" in English. This definition will later be seen to be closely related to ECCD, since enterprises must tackle various problems to proactively reduce environmental impact without sacrificing cost and quality. Thus, the following subsection examines how this cost design has been extended to global supply chains and the whole product life cycle from an environmental viewpoint.

\footnotetext{
3 The cost table (cost estimator's reference manual) sets functions, the characteristic values of specifications, processing characteristics, and volumes of similar articles against the normal actual costs of the similar articles. This is used as a handy and speedy tool for cost estimation (Tanaka 2002).

4 “...[T] $]$ he actual costs are compared against standard costs for performance evaluation and the deviations are investigated for remedial actions. Cost control is also concerned with feedback that might change any or all of future plans, production method, or both" (Siegel and Skim (2000), p. 106).
} 
Table 1 Cost design in comparison with the standard cost system

\begin{tabular}{|c|c|c|}
\hline & Cost design & Standard cost system \\
\hline Object & $\begin{array}{l}\text { To proactively manufacture value (cost } \\
\text { and function) at the design stage }\end{array}$ & $\begin{array}{l}\text { To actualize standard cost at } \\
\text { production stage }\end{array}$ \\
\hline Methods & $\begin{array}{l}\text { Proactive cost management by using ex } \\
\text { ante cost variance analysis with value } \\
\text { engineering and improvement }\end{array}$ & $\begin{array}{l}\text { Feedback cost control by means of } e x \\
\text { post cost variance analysis with } \\
\text { efficient physical and scientific } \\
\text { management }\end{array}$ \\
\hline \multirow[t]{2}{*}{ Analysis } & $\begin{array}{l}\text { Target cost based on value or on target } \\
\text { sales and target profit }\end{array}$ & $\begin{array}{l}\text { Standard cost based on standard } \\
\text { volume, standard unit price, and } \\
\text { standard capacity }\end{array}$ \\
\hline & $\begin{array}{l}\text { Estimated cost (competitive future cost) } \\
\text { is evaluated on the basis of target cost } \\
\text { (long-term planned cost) and measures } \\
\text { to improve its variance from the target } \\
\text { cost are proactively prepared during } \\
\text { the cost design stage }\end{array}$ & $\begin{array}{l}\text { Actual cost is evaluated on the basis } \\
\text { of standard cost as determined by } \\
\text { time study (time standard of each } \\
\text { task), and activities to reduce the } \\
\text { variance, defined through ex post } \\
\text { cost variance analysis, are } \\
\text { retroactively implemented at the } \\
\text { production stage }\end{array}$ \\
\hline Actions & $\begin{array}{l}\text { Proactive alteration or improvement of } \\
\text { existing cost elements, production } \\
\text { processes, methods, and organization } \\
\text { styles, based on the concept of value }\end{array}$ & $\begin{array}{l}\text { Changing purchasing methods or } \\
\text { efficient and effective usage of cost } \\
\text { elements or increasing productivity, } \\
\text { given existing cost elements and } \\
\text { manufacturing processes }\end{array}$ \\
\hline
\end{tabular}

Source: Nishimura (2003), Tanaka (1995)

\subsection{Extension of cost design to supply chains and the product life cycle}

Cost design in Japan was originally supported by subcontractors who cooperated in industrial groups (the keiretsu system), in contrast to the openly contracted supply chains in the West (Bhimani 1995; Ellram 2000, 2006; Cooper and Slagmulder 1997, 1999). In Japan, suppliers (subcontractors) to whom their parent company gives financial, technological, and informational support may find it difficult to supply other companies with their products because suppliers are dependent not only on the parent company but also on the parent company's production plan. In contrast, western-style suppliers are independent of purchasers and can select the most favorable purchaser through mutual agreement. However, this situation in Japan is becoming less prevalent, as we shall see later (Sect. 4).

To make effective and efficient use of scarce materials and provide customers with highly functional and cheap products, finished product manufacturers in Japan must establish global cooperation with suppliers. The supplier contracting system in Japan was considered a pyramid, where a large assembly company took a vertex position over the broader base of the supply tiers. For example, supply chains in the automotive industry were composed of stratified supply groups (tiers) in which entire car manufacturing companies (14 firms) closely relate to their suppliers and cooperate on information and technology; first tier (about 800 firms), second tier (about 4,000 firms) and third tier (about 20,000 firms) suppliers provided functional parts, exterior 


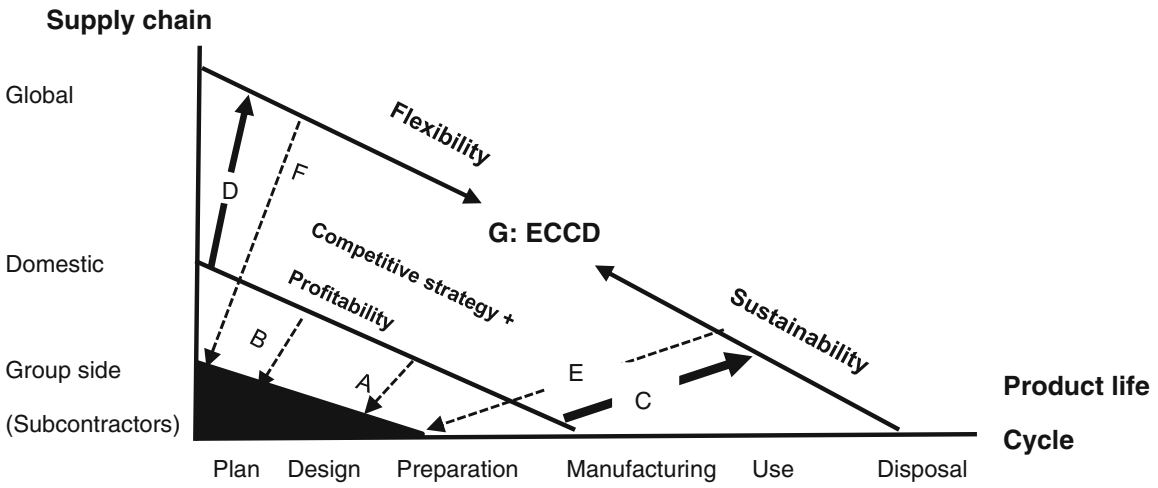

Fig. 1 Expanding cost design into environmentally conscious cost design. The black triangle shows the actual state at the stage where the cost design is carried out (supply from the group of the company or subcontractors and production preparation); arrow $A$ represents estimated product life cycle until the manufacturing stage in the initial cost design, and arrow $B$ represents the estimated domestic supply chain in the initial cost design. Both are structured from the viewpoint of profitability and competitive strategy. Dotted arrow $E$ shows the estimation sphere of the whole product life cycle in the expanded cost design, which is a result of expansion of cost design into the whole product life cycle (bold arrow $C$ ), while dotted arrow $F$ shows the estimated global supply chain in the expanded cost design, which is a result of expansion of cost design into the global supply chain (bold arrow D). G indicates the function of ECCD, into which C's sustainability and D's flexibility are integrated from the viewpoint of environmental consciousness

and interior decors, detailed parts, metal parts, and plastic parts both up the supply chain and laterally within a tier (Nabeyama 2011). In this system, suppliers who enlarge their businesses also expand their own supply chain networks. Supply chains in the transportation equipment and electric machine industries have also extended their businesses overseas, keeping step with the overseas expansion of finished product manufacturers (METI 2008; Otsuka and Ichikawa 2011; Nishimura 2008). This expansion of cost design into the global supply chain results from corporate strategy to increase manufacturing flexibility as a means of coping with the uncertainty that competitive environmental change causes (Rimiené 2011; Grigore 2007).

As rising fuel expenses and strict environmental regulations cause increases in user and disposal costs of a product in comparison with manufacturing costs, enterprises and consumers begin to think about the total lifetime cost of a product from production to disposal or recycling (Kobayashi 1996; Nakajima 2004). Although engineers may have planned and designed target costs at the design stage on the assumption that the manufacturing and selling stage is the final stage of cost design, they must now proactively build in the costs and functions across the whole product life cycle, from material procurement to production, use and disposal. Generally, the connection between life cycle costing and cost design results from business activity to offer consumers satisfaction at a cost and quality that gives a sustainable competitive advantage (Seuring 2004, 2010; Goldbach 2010). The process of expanding cost design into the global supply chain and the whole product life cycle is represented in Fig. 1.

Cost design was originally used to refer to a process of proactively manufacturing value in a production process, whereby the costs and functions of materials and parts 
from domestic suppliers and their processing costs were controlled at the design stage of a new product. In this process, as shown by dotted arrows A and B, the costs of domestic suppliers and other costs in manufacturing stage are estimated at the cost design stage, when their production conditions are relatively certain. When it extends to the whole product life cycle (bold arrow C), the company should also proactively manufacture at the design stage to control the costs and functions of a product in the complete life cycle (dotted arrow E) with an eye toward sustainability. When a supply chain becomes global (bold arrow D), a company should proactively manufacture to control the costs and functions of materials and parts in the global supply chain (dotted arrow F) by using manufacturing flexibility to cope with uncertainty. In the area of ECCD $(\mathrm{G})$, a company must take steps to reduce the environmental impact, from the material procurement stage up to the use and disposal of products by customers.

This necessitates managing quality, costs, and delivery from the viewpoints of environmental protection, particularly as it relates to resources recycling, global warming prevention, and compliance (NEC 2012). Figure 1 shows the global supply chain on the vertical axis and product lifetime along the horizontal axis. The cost design stages are spread along the horizontal and vertical directions, which are indicated by bold arrows $\mathrm{C}$ and $\mathrm{D}$, indicating an expansion of cost design to cover the product lifetime and the global supply chain. Proactive manufacturing that creates new value (or proactively building-in value) enables wider and longer processes to control costs, functions, and environmental impact at the design stage, and this result is shown as the actualization of environmental consciousness in cost management based on flexibility and sustainability.

More importantly, it is the global development of environmental consciousness that has caused cost design to simultaneously expand to global supply chains and the complete life cycle of a product. As environmental regulations become more stringent and both stockholders and consumers become more sensitive to environmental issues, enterprises should also make efforts to use environmentally friendly, functional, and cheap materials and parts so as to reduce the environmental impact across the product life cycle and produce more environmentally conscious products. Finished product manufacturers therefore tend to rely on suppliers who can offer cheaper and more environmentally friendly materials and parts. Manufacturers may also implement strict environmental assessments in the production and disposal processes of products. Enterprises are concerned with ECCD and try to proactively implement the desired environmental impact reductions, including cost, quality, and delivery targets, at the design stage of a new product. Socially responsible design, such as the safety of products, is considered in the same way as ECCD.

Enhanced environmental consciousness stimulates the need to combine cost design with global supply chain and product life cycle management organically, so that high quality and environmental impact reduction becomes integrated with cost reduction. In the following sections, we consider how cost design can evolve into ECCD. 


\section{Cost design and environmentally conscious manufacturing of Japanese companies in electric machine and transportation equipment industries}

\subsection{The present state of environmentally conscious management}

To begin, we will examine environmentally conscious manufacturing (ECM), which includes environmentally conscious products (ECPs), DFE, life cycle assessment (LCA) and eco-procurement. Data related to ECM were collected from corporate social and environmental reports disclosed mainly in 2013 (or in 2012 when undisclosed in that year) on the internet by 137 companies in the electric machine industry and 58 companies in the transportation equipment industry. These industries were chosen for discussion because the available data allow recognition of present advanced practices of cost design (particularly, ECCD) in Japan and forecasting of its future direction because they are representative industries that have underpinned the Japanese economy for a long time and have both long experience of cost design practice and experience leading the way in ECCD. The companies investigated represent 85.8 and $95.2 \%$, respectively, of each of the companies from each industry that is listed on the Tokyo Stock Exchange. Generally, ECP ${ }^{5}$ refers to a product manufactured by a firm that has adopted mainly any or all of DFE, LCA, and EP to fulfill standards of environmental impact reduction across the product life cycle. DFE is a design process that considers environmental impact reduction across the entire product lifetime, from material procurement to production, distribution, use, recycling, and disposal of a product.

As stated above, eco-procurement (sometimes called green procurement) plays an important role in ECP and is now a decisive standard of judgment by which upstream suppliers and finished products-makers select suppliers with whom to subcontract. Manufacturers and upstream suppliers give preference to those suppliers who positively address environmental issues on the basis of environmental assessment, presuming that the assessed standards will be included in the appraisal of quality, delivery, cost, and technological development and reliably achieved (Sumida Group 2012). LCA refers to activities to quantify environmental impact over the complete product lifetime, from materials procurement to product disposal (Mitsubishi Electric Corporation 2002, 2010). Table 2 shows how the investigated companies carry out ECM. The relation between ECP and other environmental manufacturing methods is indicated in Table 3. Here, we see that ECP $(60.5 \%)$ is linked closely with eco-procurement $(61.5 \%)$ and LCA (44.6\%). This situation suggests that overall ECP is never implemented in a systematic form based on DFE. Where ECP strongly connects with DFE, LCA, and eco-procurement (EP), the probability of ECCD implementation is assumed to be high since DFE is easily connected to cost design at the design stage.

In Table 3, we see that 66 companies from among 195 (about 33.8\%) implement ECP in a form strongly connected with DFE, LCA, and EP, while the rest (44) of

\footnotetext{
5 Toshiba group describes ECP in its environmental report as follows: "We will accelerate the creation of ECPs with high levels of environmental performance in all product areas through 'Greening of Products' initiatives aimed at minimizing the environmental impact of products throughout their entire life cycles and 'Greening by Technology' initiatives aimed at providing a stable power supply and mitigating climate change worldwide using low-carbon energy supply technology" (Toshiba 2013, p. 23).
} 
Table 2 Present state of environmentally conscious manufacturing

\begin{tabular}{|c|c|c|c|c|}
\hline Industry (number of investigated companies) & $\mathrm{ECP}$ & DFE & LCA & $\mathrm{EP}$ \\
\hline \multicolumn{5}{|l|}{ Electric machine } \\
\hline Number of companies (out of 137) & 76 & 46 & 59 & 86 \\
\hline Ratio (\%) & 55.5 & 33.6 & 43.1 & 62.8 \\
\hline \multicolumn{5}{|l|}{ Transportation equipment } \\
\hline Number of companies (out of 58) & 42 & 29 & 28 & 34 \\
\hline Ratio (\%) & 72.5 & 50 & 48.3 & 58.6 \\
\hline \multicolumn{5}{|l|}{ Total } \\
\hline Number of companies (out of 195) & 118 & 75 & 87 & 120 \\
\hline Ratio (\%) & 60.5 & 38.5 & 44.6 & 61.5 \\
\hline
\end{tabular}

Source: corporate social and environmental reports in the two industries ECP environmentally conscious product, DFE design for environment, $L C A$ life cycle assessment, EP eco-procurement

Table 3 Relations between ECP and other environmental manufacturing methods

\begin{tabular}{llllrr}
\hline Industry & $\begin{array}{l}\mathrm{ECP}+\mathrm{DFE} \\
+\mathrm{LCA}+\mathrm{EP}\end{array}$ & $\begin{array}{l}\mathrm{ECP}+\mathrm{DFE} \\
+\mathrm{LCA}\end{array}$ & $\begin{array}{l}\mathrm{ECP}+\mathrm{DFE} \\
+\mathrm{EP}\end{array}$ & $\begin{array}{l}\mathrm{ECP}+\mathrm{LCA} \\
+\mathrm{EP}\end{array}$ & $\mathrm{ECP}+\mathrm{EP}$ \\
\hline Electric machine & 40 & 3 & 1 & 13 & 18 \\
Transportation equipment & 26 & 1 & 2 & 1 & 5 \\
Total (110) & 66 & 4 & 3 & 14 & 23 \\
\hline
\end{tabular}

In addition to the companies indicated in the table, there are eight companies that report carrying out only ECP without identifying any other methods. As a result, we can see that 118 companies implement ECP conjointly with any or all of DFE, LCA, and EP, or only EP $(=110+8)$. We may note, in passing, the situation of other environmental manufacturing methods: one company in DFE + LCA + EP, 2 in LCA + EP, 1 in DFE, and 11 in EP. 62 companies identify nothing about environmental manufacturing

110 companies that report any relation of ECP to other environmental manufacturing methods do so in a partial form, where it is supported mainly by an environmentally conscious supply chain network. It is also important to consider that ECP is strongly supported by EP. It may be inferred from Table 3 that $26(44.8 \%)$ of the 58 investigated companies in the transportation equipment and $40(29.2 \%)$ of the 137 in the electric machine industry may carry out ECP in a comprehensive form based on DFE, LCA, and EP, which may also be related to ECCD (setting aside what type of cost design the companies adopt), since another survey Park (2009) showed that $82.6 \%$ of companies in the transport equipment industry carry out DFE and $87 \%$ implement cost design. This is in contrast to 85.7 and $67.6 \%$, respectively, in the electric machine industry. In this research as well as that of Kajihara et al. (2009), when recycling, design, and environmental assessments are regarded as DFE, the research shows a higher rate of implementation for DFE than that shown in our results, in which DFE is separated from LCA and eco-procurement. The rate of ECCD implementation would thus be lower in our study than in the findings by Kajihara et al. if DFE represents ECCD; this is because DFE in our study has a narrower definition than in their studies: $38.5 \%$ as a whole, and 33.6 in the electric machine industry and $50 \%$ in the transportation equipment industry. Additionally, as discussed in Sect. 2, we must consider the function of ECCD, 
or integration of flexibility and sustainability based on profitability and competitive strategy in process in which cost design expands into global supply chain and the whole product life cycle. Therefore, ECCD may certainly take a comprehensive shape through the connection of DFE with LCA and EP. We cannot assume a rate of ECCD implementation higher than about $35 \%$. This may also be supported by the research of JAMS in 2009, when only 20-24\% of the investigated companies included costs for environmental preservation in target costs (JAMS 2009).

Even if we assume an implementation rate of ECCD at about $35 \%$ on the presumption that ECCD is carried out when ECP is closely connected to DFE, LCA and $\mathrm{EP}$, it is debatable what form of ECCD each company adopts and what procedures enterprises follow when integrating low cost, high quality, and environmental impact reduction with ECCD.

\subsection{Structures and problems of environmentally conscious cost design}

Ito (2007) and METI (2002) present two types of ECCD: a unified type, which proactively targets costs based on the value concept and targets environmental impact reduction simultaneously at the design stage, and a two-layer type, in which the target level in DFE is decided on the basis of business policy before product development, separating items of expenditures related to DFE from target cost allocation (Ito 2007). Sony, a major electrical manufacturer that adopts the unified type, "has added environmental quality considerations to Sony's procurement system, while quality, cost, delivery and service are obviously essential" (Sony Corporation 2001, p. 22). Already in 1991, the corporation, acting on the belief that product quality is inseparable from environmental quality, launched "a full-scale product assessment program that included environmental factors in its overall definition of product quality" (Sony Corporation 2001, p. 28). At Toyota, which has created and developed its own cost design system, the chief engineer responsible for development of a particular vehicle also sets environmental impact reduction targets for that vehicle in accordance with a comprehensive environmental impact assessment system that functions for systematically assessing a vehicle's impact on the environment over the entire life cycle from the design stage through to the production, use, and disposal stages (Toyota Motor Corporation 2011, 2013).

Figure 2 shows how "Sony's comprehensive approach to environmentally conscious operations begins with product assessment during product planning and design" (Sony Corporation 2001, p. 28). For the first assessment of environmental impact [labeled (a) in Fig. 2], five significant items of environmental impact in the hypothetical scenario of a Camcorder TSE/3000 (a video camera) are picked according to an environmental management system related to ISO 14001, which concerns electrical consumption, electricity used during standby, the number of parts used, the solder, and packing materials. Each environmental impact reduction target [labeled (b) in Fig. 2] is then compared with similar models available at the time of conception and design. Changes such as a reduction in electrical consumption from 10 to $8 \mathrm{~W}$ and a switch to lead-free solder are examples of the types of changes made to reduce environmental impact (Ito 2007). In addition, the priority given to these items is decided and the cost of production is reexamined as compared with the initial target cost (functional and cost targets). 


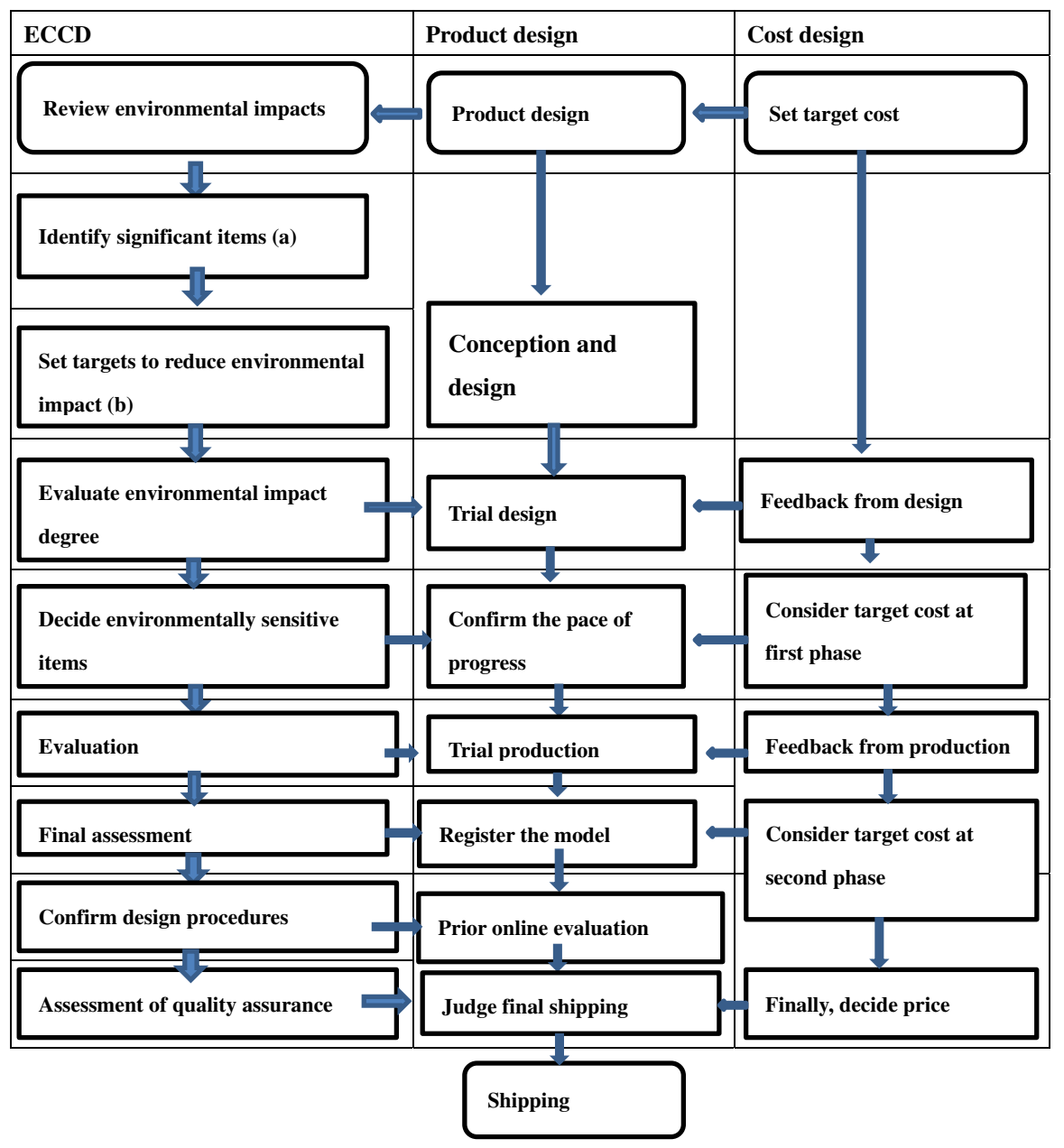

Fig. 2 Unified type of ECCD in Sony Corporation. Source: Ito (2007), METI (2002)

Sony computes the monetary conversion of the environmental impact reduction performance "by applying Sony's original monetary conversion coefficients as well as by comparing the environmentally conscious design cost with the environmental impact reduction performance in terms of such factors as energy conservation, and weight, polystyrene foam, and leaded solder reduction" (Sony Corporation 2001, p. 31). Denso Corporation, an automotive parts manufacturer, also uses environmental efficiency index to compare new and existing products to balance between environmental impact reduction and product value. Regarding the index, product value (a positive factor) and environmental impact (a negative efficiency index to compare new and existing products to provide an environmental impact reduction factor) of the new product are normalized to the values for existing products to create an index number (Denso Corporation 2010, 2014). 
Finance Department

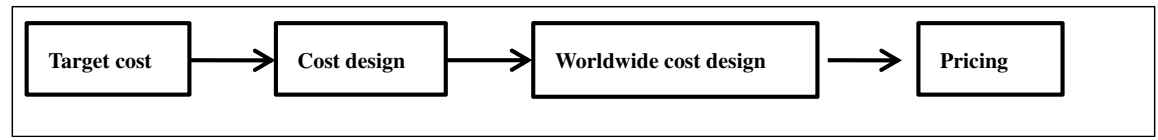

\section{ECP development for integrated product development}

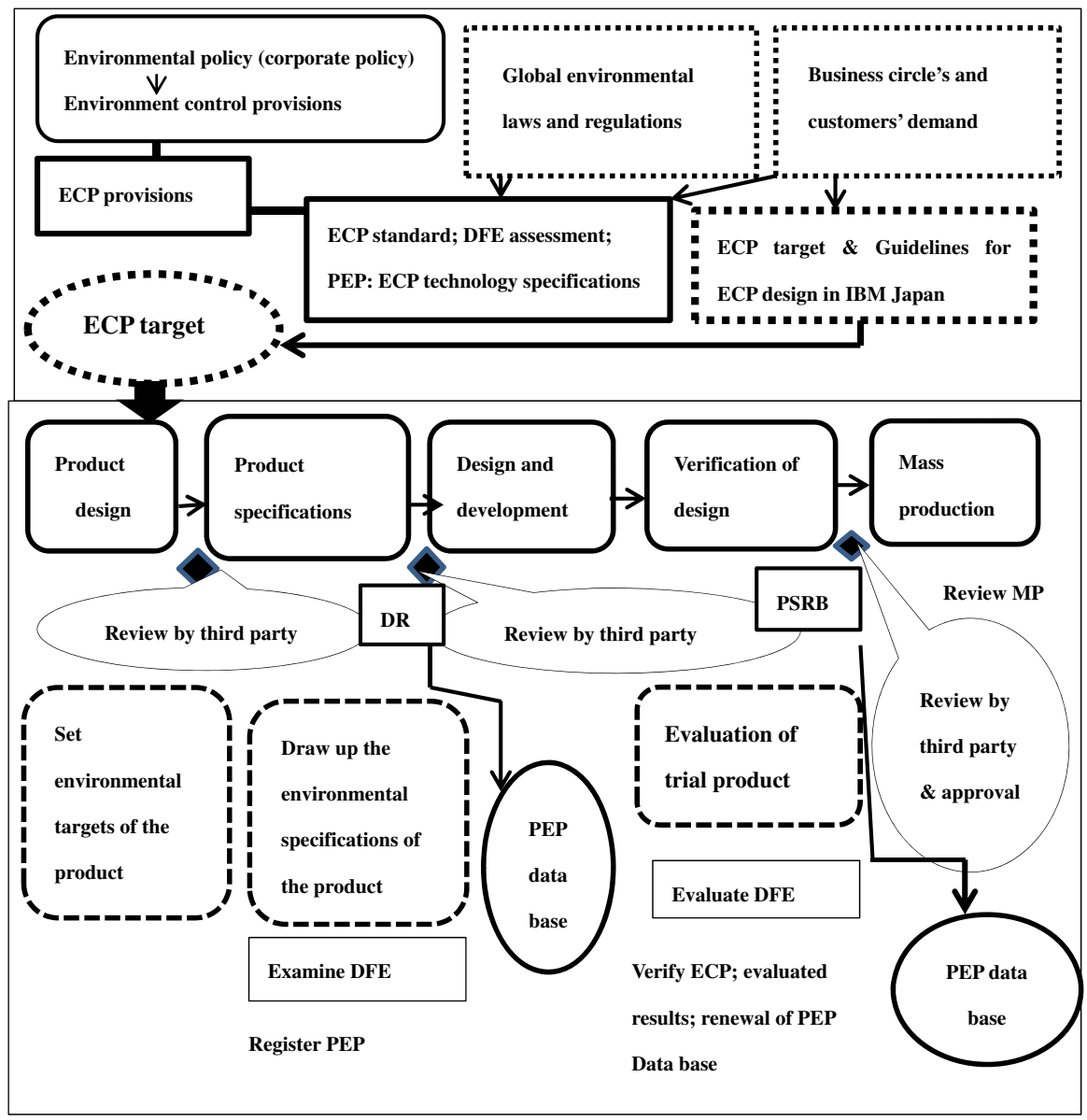

Fig. 3 The two-layer type of ECCD in IBM Japan. PEP product environmental profile, ECP environmentally conscious product, $D F E$ design for environment, $D R$ design review, $P S R B$ product safety review board. Source: Ito (2007); IBM Japan 2001 (see also IMB Environmental Conscious Product Design on the web site)

As stated above, Sony implements ECCD by combining DFE, product design, and cost design (Fig. 2). In contrast, IBM Japan implements our definition of DFE, formally separating it from cost design, although the target of environmental impact reduction and life cycle assessment links closely with cost design in terms of ECCD. This twolayer type is shown in Fig. 3. IBM Japan, which carried out environmental impact assessment programs in 1978, expanded this to ECP programs and started implement- 
ing simple and easy-to-handle DFE in 1991 (IBM Japan 1999, 2000; Yamamoto and Kokubu 2001). In ECCD, the corporation's finance department implements "accurate and impartial costing, and uses the whole value related to the procurement of materials and parts in the whole company, not departmental costing, to establish a scheme for cost design" (Ito 2007, p. 54). However, DFE and cost design are connected by the Integrated Product Development process. DFE is implemented under the integrated product development plan, in which new products are developed under a global standard and the applicable scope includes all life cycle processes of a newly developed product. During implementation, it is important to set up and actualize targets of quality, cost, and delivery, while realizing environmental targets. In developing a new ECP, the need to 'proactively manufacture' the product at the early stage of development plays a critical role in determining the environmentally conscious level of a finished product. At the same time, IBM Japan began to emphasize EP (IBM Japan 2001).

As indicated in Tables 2 and 3, about $35 \%$ of the companies investigated in the two industries (75 in Table 2 and 66 in Table 3 of 195) are assumed to carry out either of the two types of ECCD discussed above, assuming that ECP based on DFE and connected with some of other three factors represents ECCD. We also note that the success or failure of ECCD is highly dependent on finished product manufacturers' environmental management and their cooperation with suppliers, since ECCD has a critical need to proactively build-in low cost, high quality, and minimum environmental impact of materials and parts at the design stage and to proactively assess the above factors over the complete product life cycle. This is because expenditures to suppliers are a large portion of production costs, as shown in Table 4 of Sect. 4. Although we can understand the general state of ECCD from the figures shown, we do not have a great deal of information on concrete practical models (in particular, a fundamental category combining the three factors) and their detailed procedures. We should extend our observation to include the relation between ECCD and eco-procurement to investigate the likelihood of adoption and problems for its further development. In practice, ecoprocurement plays an important role in realizing DFE effectively.

\section{Eco-procurement and the future development of environmentally conscious cost design}

\subsection{Problems and challenges}

It is worthwhile to quantify the expense of materials and supplier's processing costs 6 within the manufacturing costs of finished product manufacturers in the electric machine and transport equipment industries as a means of clarifying the importance of supply chains for ECCD. Table 4 shows how companies in both industries depend strongly upon suppliers, despite a difference between concentrated dependency in the transportation equipment industry and the more dispersed type in the electric machine industry. One of the more critical aspects in ECCD for finished product manufacturers

\footnotetext{
6 Here, the amount paid to subcontractors and processing expenses arising from outside manufacturing is simply defined as suppliers' processing costs.
} 
Table 4 Rate of material costs and suppliers' processing costs in manufacturing costs

\begin{tabular}{llllll}
\hline Cost elements & \multicolumn{2}{l}{ Material costs } & & \multicolumn{2}{l}{ Suppliers' processing costs } \\
\cline { 2 - 3 } \cline { 5 - 6 } Industry & $\begin{array}{l}\text { Transportation } \\
\text { equipment }(\%)\end{array}$ & $\begin{array}{l}\text { Electric } \\
\text { machine }\end{array}$ & & $\begin{array}{l}\text { Transportation } \\
\text { equipment }(\%)\end{array}$ & $\begin{array}{l}\text { Electric } \\
\text { machine (\%) }\end{array}$ \\
\hline Median & 69.5 & & & & \\
Standard deviation & 15.1 & 20.8 & & 9.6 & 9.4 \\
Minimum & 22.9 & 0.8 & & 0.03 & 17.5 \\
Maximum & 88.1 & 96.1 & & 37.9 & 0.03 \\
Sample points & 55 & 133 & & 55 & 82.3 \\
\hline
\end{tabular}

Data were collected from corporate social and environmental reports in the manner described in Sect. 3.1

and upstream suppliers is the selection of subordinate suppliers (or subcontractors) in parallel with innovation of their own manufacturing processes and methods. IBM Japan points out the importance of green supply chains for ECP as follows. Cost competitiveness is an important factor for the corporation and it is critical to minimize production costs by becoming a more environmentally conscious enterprise. The reduction of environmental countermeasure costs in material cost through the elimination of waste and the minimization of energy costs through the reduction of the energy used for production is necessary for this purpose. Speedy correspondence with parts and materials manufacturers along the supply chain including the development of information technology is essential to proactively manufacture environmental quality in the development of a new product under ever-changing materials and parts (IBM Japan 2001).

Toyota also requires materials and high quality parts at low cost with quick delivery and assurances of environmental safety from suppliers according to their Green Purchasing Guidelines: “Toyota expects its business partners to ensure 'long-term and stable procurement of the best products at the lowest price in the most speedy and timely manner,' based on thorough compliance with all applicable laws, regulations, and social norms and consideration for the environment. From the standpoint of customers who purchase our products, we ask you to 'build quality' into all processes for Toyota products, from development to production and shipment/logistics" (Toyota Motor Corporation 2011, p. 2). A green supply chain and its management play an important role in the development of ECP or ECCD in Japan as well as in the West (Kajüter 2002; Cooper and Slagmulder 1997).

\subsection{Questions and possible solution under complicated supply chain system}

The Great East Japan Earthquake of March 2011 marked a change in the relationship between finished product manufacturers and suppliers. Although before the earthquake all Japanese auto manufacturers were thought to control all supply chains from tier 1 to tier 3, these chains were cut into pieces and manufacturers were compelled to suspend business for several months as they were unable to control the new supply chain (Nabeyama 2011). The supply chain has since changed from a closed, simple structure, 
such as the pyramid type previously described, to a multilayered and complicated structure, such as a diamond or mesh structure, where the enhanced diversification and concentration of production, as well as the loose relationships among suppliers has made the whole supply chain both invisible and uncontrollable (Otsuka and Ichikawa 2011). As advancing technology increases the specialization and division of work, suppliers have not only shifted from the supply of parts inside the same group (e.g. Toyota) to diversified supply to other groups (e.g. Nissan or Honda), but they have also accelerated the extensive division of work wherein a supplier in the first or second tier not only directly provides an entire car manufacturing company with parts but also sells parts to other suppliers. The intensive tendency of supply chains is also increased through mergers and reorganization undertaken to improve productivity and raise value added after the Great East Japan Earthquake. This tendency of big suppliers in the first and second tiers gives rise to more intricate relationships among suppliers, who use multifarious methods and networks to establish an efficient and effective supply chain system (Otsuka and Ichikawa 2011).

As a result, the weakness of the close and visible supply chain, in which a supplier served a finished product manufacturer in a crucial capacity and other suppliers in the related group, was exposed after the earthquake. The invisibility and uncontrollability that arose caused increased complexity and weakened relations among suppliers. In addition, the search for rich resources and cheap labor prompted many suppliers to move to East Asia (METI 2008), touching off a price war that has only increased the complexity and invisibility of the supply chain structure. Those enterprises that carried out cost design on the basis of close and visible relation to suppliers are now faced with the problem of how to make visible and control the wide and long-term relations to suppliers and other interested parties, such as carriers and collecting/recycling dealers, in a way that ensures manufacturing flexibility and sustainability.

ECCD is a system to surmount not only the problem of lowering costs while increasing quality but also the antagonistic relation between these two factors and the problem of reducing environmental impact (Beppu 2005). ECCD is a process to proactively build-in the three factors over a wide supply chain and the whole life cycle of a product. The reason we cannot find many definite models of ECCD is due to the difficulty of estimating the costs related to wide and complicated supply chains and the entire life cycle of a product at the design stage.

The diversified and complicated nature of supply chains can make the cost estimating process obscure and uncontrollable, even as large finished product manufacturers strengthen the unity of their groups in order to control the whole supply chain through group-internal cooperation. Because of this, enterprises find it difficult to estimate and proactively manufacture for cost, quality, and the environmental impact of supplier materials and parts at the design stage. Moreover, enterprises must work to estimate not only the costs over the product lifetime, but also cope with the changing life of the product in competitive markets (Orita 2012). Finished product manufacturers should establish a strongly green and socially responsible partnership with suppliers (Lavastre et al. 2012; Thun and Hoenig 2011; Cheng et al. 2012) to develop improved competitiveness, profitability, and long-term sustainability (Lockamy and Smith 2000).

However, in Japan where there is little room left in the cost design for cost reduction, this often leads to a deterioration of quality, which can in turn lead to product recalls, 
since enterprises may compel suppliers to produce parts at lower cost to achieve the target cost of a product (Kato 2010). At times, severe curtailment of costs (by setting strict cost targets in factories or through requiring lower costs of suppliers) and stricter environmental requirements lead to a reduction in the level of functioning of the vehicles. Recall-related costs are a pure waste of social resources that the suppliers, managers, and workers of an assembly firm could otherwise use in an effort to manufacture cheap, functional, and environmentally friendly products. Thus, in effect, these costs are also environmentally unfriendly activities. Under the prevailing cost design systems in Japan, it is most critical to find ways to proactively manufacture costs, quality, and environmental impact reduction into products and tackle recall-level problems from the viewpoint of profitability, competitive strategy, and social responsibility. Although auto manufacturers and big electronics companies seek to increase the uniformity of their supply chain through information sharing and technological and financial support, there still remain some problems of visibility and control in cost design. Even today, recalls by auto manufacturers of defective vehicles is a serious problem. The recall of 1.9 million Prius automobiles was the result of improper programming for the hybrid control system, which Toyota produced from March 2009 to February 2013 and sold globally (The Nikkei 2014). From among Honda hybrid cars, 81,353 of two different types produced from July 2013 to February 2014 were also recalled (Nikkan Kogyo Shinbun 2014). According to an analysis of automobile recall notifications published by the Road Transport Bureau of METI, $59.5 \%$ (122) of all notified recalls (205) in 2011 resulted from "design problems," and 109 recalls $(53.2 \%$ of the whole and $89.3 \%$ of the 122) were caused by lax evaluation standards (Road Transport Bureau 2013). The average results over five years, from 2007 to 2011, show almost the same tendency as that in 2011. The recall of defective vehicles by Japanese auto manufacturers that are the result of design problems exemplifies the difficulty of balancing cost design with environmental impact reduction in ECCD.

At the individual company level, the most important aspect of ECCD implementation is to find and establish a fundamental category, analogous to value in the initial cost design, which will make it possible to simultaneously quantify and evaluate the cost, functions, and environmental impact of a product. However, some skepticism about the development of this fundamental category seems reasonable, since we depend here on the efforts of companies, changes in social environmental consciousness, and the strong support of governments and industrial circles, which will all play a role in resolving the environmental problems that have resulted from global socioeconomic development. For example, to effectively implement ECCD, individual companies must use cost tables at the functional level that are prepared with the aid of product environmental information and databases on regulated chemical substances, prohibited materials use, and energy-conserving technologies in each industrial sector. These tables are also indispensable for the ultimate goal of sustainability, which is to "achieve a better balance of environmental protection and social equity" in the economy (Swarr and Hunkeler 2008. p. 85). Information on these items from each industrial sector, even if the cooperation of firms, industrial groups, and national governments is necessary in terms of finance and activities, may help nurture the development of ECCD in the same way that Japanese motor companies could hasten to produce environmen- 
tally friendly vehicles on the model of the International Material Data System ${ }^{7}$ and the Global Automotive Declarable Substance List. ${ }^{8}$ In the electric machine industry, the recycling cost table ${ }^{9}$ of the office machine and optical instrument manufacturer, Ricoh (Kokubu and Nakashima 2003), which makes use of life cycle costing in ECCD, could be more effectively supported not only by industrial group (e.g. by PC3R, an association to promote the reduction, reuse, and recycling of personal computers) but also by governments as a source of information (PC3R Promotion Association 2014).

\section{Conclusion}

In ECCD, Japanese companies must solve the problem of proactively and reliably manufacturing cheaper and more functional products with minimal environmental impact at the design stage under increasing uncertainty and complexity caused by broadening supply chains and the diverse, intricate relationships among suppliers and other dealers (producers, users, retailers, and collecting/recycling dealers) in the life cycle process. ECCD, when used on the basis of the initial cost design with the intention of profitability and competitive strategy, performs its social and environmental duties by integrating flexibility and sustainability into it as a result of the initial cost design's expanding to global supply chain and the whole product life cycle. Therefore, ECCD becomes more complicated than the initial cost design. The core of all the questions is whether Japanese enterprises continually follow management thinking to solve the inherently antagonistic relation between low cost and high quality, and minimal environmental impact in ECCD by proactively manufacturing for all of these factors at the design stage or whether they modify its thinking and use a trade-off between cost and environmental impacts to seek a well-balanced combination. Thanks to the success of cost design, the idea of cheap, high quality goods has taken root in the minds of Japanese consumers. Consumers have become accustomed to corporations taking efforts toward environmental protection without passing on these costs, even as producers wrestle with the problem of producing a low cost product that has minimal environmental impact. Japanese enterprises should continue to look inward and outward for cost and quality improvements.

The most important point is to deepen national environmental awareness and for each person to bear the social and environmental costs in his or her own way. In this situation, enterprises can use ECCD to proactively manufacture with reasonable target costs, at high quality, and with low environmental impact. For example, they may use a metric such as socioeconomic value, in which functional improvement and environmental impact reduction curves will intersect at an optimum cost. However, this problem is not only on the company side. Industrial organizations and governments

\footnotetext{
7 IMDS is a system that collects information on about 30,000 types of parts and chemical substances contained in supply chains (Hewlett Packard 2014).

8 GADSL has the purpose of facilitating communication and exchange of information regarding the use of certain substances in automotive products throughout the supply chain (GADSL 2011).

9 A recycling cost table is used to evaluate environmental costs on the basis of the relation between cost analysis induced by life cycle costing and physical analysis based on the evaluation of product environmental impacts. (Kokubu and Nakashima 2003).
} 
must also contribute to the realization of the goals of ECCD. Although difficult, both enterprises and consumers in Japan must now embark on a new path in which they must contribute to environmental protection in their own ways since environmental problems take a long time and global effort to solve. The efforts of the government and industrial organizations have led to several advances in environmental manufacturing and management in Japan. These include tax breaks for eco-friendly cars and energy-saving household electric appliances, environmental regulations, and public environmental protection activities.

As Japanese enterprises begin to implement ECCD, there will be room after several years for further investigation of its practical state. However, the framework and fundamental concepts of ECCD have already been implemented in some companies and will be further refined in the future. At the same time, future study in management accounting will considerably shift viewpoints from thinking in divisions or units of company (the unitary systematic approach) to a systems-thinking approach (Rebitzer 2010), including environmental and, perhaps, social aspects (Lichtenvort et al. 2008). This paper examined the possibility for cost design to transform into ECCD and pointed out the difficulty of this transition and problems for its further development. The fundamental thinking discussed in this paper may be in line with socioeconomic studies in management accounting, which accounting researchers must undertake when they investigate socioeconomic issues such as the safety of products and environmental consciouness focused on profitability and competitive strategy.

Acknowledgments This paper was made possible through Grants-in-Aid for Scientific Research (20132015) from the Japan Society for the Promotion of Science. I would like to acknowledge here the generosity of this organization.

Open Access This article is distributed under the terms of the Creative Commons Attribution License which permits any use, distribution, and reproduction in any medium, provided the original author(s) and the source are credited.

\section{References}

Beppu, Y. (2005). Environmental management and business strategy: Tapahe case studies of Japanese companies in Oceania (3). The Teikyo University Economic Review, 38(2), 25-73.

Bhimani, A. (1995). Target excellence: target cost management at Toyota in the UK. Management Accounting, 73(2), 42-45.

Cheng, T. C. E., Yip, F. K., \& Yeung, A. C. L. (2012). Supply risk management via guanxi in the Chinese business context: the buyer's perspective. International Journal of Production Economics, 139, 3-13.

Cooper, R., \& Slagmulder, R. (1997). Target costing and value engineering. Oregon: Institute of Management Accounts, Productivity Press.

Cooper, R., \& Slagmulder, R. (1999). Develop profitable new products with target costing. Sloan Management Review, Summer, 40(1), 23-33.

Denso Corporation. (2010). Supplier CSR guidance, April 6.

Denso Corporation. (2014). Product-environmental management. http://www.denso.co.jp/ja/csr/ environment_report/management/product/index.html/. Accessed 9 April 2014.

Ellram, L. M. (2000). Purchasing and supply management's participation in the target costing process. The Journal of Supply Chain Management, Spring, 36(2), 39-51.

Ellram, L. M. (2006). The implementation of target costing in the United States: theory versus practice. The Journal of Supply Chain Management, Winter, 42(1), 13-26. 
Gabriel, M., Tschandl, M., \& Posh, A. (2014). Sustainability-oriented lifecycle costing. International Journal of Engineering, 12(1), 33-40.

GADSL. (2011). Global Automotive Declarable Substance List: Guidance Document, 2011-2012. http://plastics.americanchemistry.com/Stand-Alone-Content/Global-AutomotiveDeclarabble-Substance=Document/. Accessed 14 March 2014.

Goldbach, M. (2010). Organizational settings in supply chain costing. In v Seuring \& M. Goldbach (Eds.), Cost management in supply chains (pp. 89-108). Heidelberg: Physica-Verlag.

Grigore, S. D. (2007). Supply chain flexibility. Romanian Economic and Business Review, 2(1), 66-70.

Gungor, A., \& Gupta, S. M. (1999). Issues in environmentally conscious manufacturing and product recovery: a survey. Computers and Industrial Engineering, 36, 811-853.

Henri, J.-F., \& Joumeault, M. (2010). Eco-control: the influence of management control systems on environmental and economic performance. Accounting, Organizations, and Society, 35(1), 63-80.

Hewlett Packard. (2014). International Material Data System to Automotive Industry. http://h50146.www5. hp.com/solutions/industry/manufacture/sol/imds/. Accessed 14 March 2014.

Horváth, P., \& Berlin, S. (2012). Green target costing; getting ready for the green challenge!. Cost Management, 26(3), 25-36.

Hunkeler, D., Lichtenvort, K., \& Rebitzer, G. (ed.) (2008). Environmental life cycle costing. Boca Raton: CRC Press, Taylor \& Francis Group.

IBM Japan. (1999). Environment and well-being progress report 1999: Environment and Safety/Sanitation/Health, pp. 10-11.

IBM Japan. (2000). Environment and well-being progress report, pp. 16-17.

IBM Japan (2001). Environment and well-being progress report 2001, 24-25; as for the relation between product development and ECP based on Integrated Product Development Plan, and green supply chain, see the released documents on Green Supply Chain: IBM Environmental Conscious Product Design (Green PLM). http://www-06.ibm.com/services/bcs/jp/solutions/sc/menu/green_plm.html. Accessed 17 February 2014.

Ilgin, M. A., \& Gupta, S. M. (2010). Environmentally conscious manufacturing and product recovery (ECMPRO): a review of the state of the art. Journal of Environmental Management, 91, 563-591.

IMA. (1994). Implementing target costing, statements on management accounting. Canada: Institute of Management Accountants.

Ito, Y. (2006). Subjects of environmentally conscious cost design. Accounting, 170(4), 485-499.

Ito, Y. (2007). Investigation and research on environmentally conscious cost design, report to Japan Society for Promotion of Science, May, 37-40.

JAMS. (2005). The situation and subjects of cost design in Japanese leading companies, research report to Japan Society for Promotion of Science, 2004-2005: Japanese Association of Management Researchers (JAMS).

JAMS. (2009). The situation and subjects of cost design in Japanese leading companies, 2008-2009's survey by JAMS.

Kajihara, T., Park, K. Y., \& Kato, Y. (2009). Environmentally conscious design and cost design: preparatory investigation on survey research. Kokumin-Keizai Zasshi (Journal of National Economy), Kobe University, 199(6), 11-28.

Kajüter, P. (2002). Proactive cost management in supply chains, in Seuring, S., \& Goldbach, M. (eds.) Cost management in supply chains. Heidelberg: Physica-Verlag (pp. 31-51).

Kato, N. (2010). Discussion on impoverished problems of suppliers in cost design. Oita University Economic Review, 62(1), 23-49.

Kato, Y. (1993a). Target costing support systems: lessons from leading Japanese companies. Management Accounting Research, 4, 37-47.

Kato, Y (1993b). Cost design: strategic cost management. Tokyo: Nikkei Newspaper Office.

Kato, Y., Böer, G., \& Chow, C. W. (1995). Target costing: an integrative management process. Journal of Cost Management, 9(1), 39-51.

Kobayashi, T. (1996). Life cycle cost and cost design. Kokumin-Keizai Zasshi (Journal of National Economy), Kobe University, 173(3), 1-13.

Kokubu, K., \& Nakashima, M. (2003). Environmental accounting in Ricoh company. Kokumin-Keizai Zasshi (Journal of National Economy), Kobe University, 188(3), 41-56.

Kreuze, J. G., \& Newell, G. E. (1994). ABC and life-cycle costing for environmental expenditures. Management Accounting, 75(8), 38-42. 
Lavastre, O., Gunasekaran, A., \& Spalanzani, A. (2012). Supply chain risk management in French companies. Decision Support Systems and Electronic Commerce, 52, 828-838.

Lichtenvort, K., Rebitzer, G., Huppes, G., Ciroth, A., Seuring, S., Schmidt, W-P., Günther, E., Hoppe, H., Swarr, T., \& Hunkeler, D. (2008). History of life cycle costing, its categorization, and its basic framework. In Hunkeler, D., Lichtenvort, K., \& Rebitzer, G. (eds.) Environmental life cycle costing. Boca Raton: CRS Press.

Lockamy, A., \& Smith, W. (2000). Target costing for supply chain management: criteria and selection. Industrial Management + Data Systems, 100(5), 210-218.

METI. (2002). Environmental management accounting (EMA) workbook. Japanese Ministry of Economy, Trade and Industry.

METI. (2008). White paper on manufacturing industry (Monotsukuri) in 2007, June, Joint Project with Ministry of Health, Labor, and Welfare, and Ministry of Education, Culture, Sports, Science and Technology (pp. 18-45)..

Mitsubishi Electric Corporation. (2002). Environmental sustainability report.

Mitsubishi Electric Corporation. (2010). Corporate social responsibility environmental report.

Monden, Y. (1999). Cost design schedule of automobile industry. In Y. Monden, K. Hamada, \& K. Lee (Eds.), Japanese cost management, in Japanese (pp. 115-127). Tokyo: Dobunkan Publisher.

Monden, Y., \& Hamada, K. (1991). Target costing and kaizen costing in Japanese automobile companies. Journal of Management Accounting Research, Fall, 3, 16-34.

Nabeyama, T. (2011). Examination of supply chain reconstruction after the Great East Japan Earthquake, Joyo ARC, AREA Research Center, September, 6-11.

Nakajima, Y. (2004). Treatment of life cycle costs in target costing, study of business management, 21, September (pp. 119-139).

NEC. (2012) 2012 Environmental activity report. http://www.nec.com/en/global/eco/product/eco_pro/ index.html/. Accessed 19 February 2014.

Nikkan Kogyo Shinbun. (2014). Recall of the Two Types of Cars in Honda: Fit Hybrid Cars, Daily Industry Newspaper Ltd, February 11. http://www.nikkan.co.jp/. Accessed 22 February 2014.

Nishimura, A. (2003). Management accounting: feed forward and Asian perspectives. Hampshire: Palgrave Macmillan.

Nishimura, A. (2008). Effect of management system on management accounting: the case of chinese cellular phone terminal unit manufacturers. Asia-Pacific Management Accounting Journal (APMAJ), 4(1), 87-105.

Orita, Y. (2012). The whole company's improvement process of cost management: reexamination of management accounting for manufacturing (Case Study of Fuji Xerox Company). Report presented in the third forum (December, Tokyo), The Japanese Association of Management Accounting.

Otsuka, T., \& Ichikawa, Y. (2011). How is Japanese supply chain judged? Mizuho Research Institute Review, $3,1-9$.

Park, K. P. (2007). Subjects on environmental conscious development. Economic Review, Kagawa University, 79(4), 87-108.

Park, K. P. (2009). Fact finding of environmental conscious product issues. Research Report, 49, $73-93$.

Parker, L. D. (2000). Green strategy costing: early days. Australian Accounting Review, 10(1), 46-55.

PC3R Promotion Association. (2014). Guideline of PC3R Promotion Association. http://www.pc3r.jp/ association/index.html/. Accessed 14 March 2014.

Pondeville, S., Swaen, V., \& Rongé, Y. D. (2013). Environmental management control systems: the role of contextual and strategic factors. Management Accounting Research, 24(4), 317-332.

Rebitzer, G. (2010). Integrating life cycle costing and life cycle assessment for manufacturing costs and environmental impacts in supply chains. In Seuring, S., \& Goldbach, M. (eds.) Cost management in supply chains. Heidelberg: Physica-Verlag. (pp. 127-146).

Rimiené, K. (2011). Supply chain agility concept evolution (1999-2010). Economics and Management, 16, 892-899.

Road Transport Bureau. (2013). The Analyzed Results of Contents Notified as Recall of Cars. Japanese Ministry of Land, Infrastructure, Transportation and Tourism, April: Road Transport Bureau. 19.

Sakurai, M. (1989). Target costing and How to Use it, Journal of Cost Management, Summer, 3(2), 39-50.

Sakurai, M. (1991). Change in business environment and management accounting. Tokyo: Dobunkan Publisher.

Sarkis, J. (1995). Manufacturing strategy and environmental consciousness. Tech-novation, 15(2), 79-97. 
Sato, Y. (2009). The soul of cost design (1): Nikkei Monotsukuri (Manufacturing), September, (pp. 113116).

Seuring, S. (2004). Industrial ecology, life cycles, supply chains: differences and interrelations. Business Strategy and the Environment, 13, 306-319.

Seuring, S. (2010). Supply chain target costing: an apparel industry case study. In Seuring, S., \& Goldbach, M. (ed.), Ibid. (pp. 111-125).

Siegel, J. G. \& Skim, J. K. (2000). Dictionary of accounting terms, 3rd edn. New York: Barron's Educational Series Inc.

Sony Corporation. (2001). Environmental report 2001: entertaining the world, caring for the future. http:// www.sony.co.jp//SonyInfo/csr_report//2001/qfhh7c00000d76pv_att/copy_of_2001_all.pdf. Accessed 15 August 2013.

Steen, B. (2005). Environmental costs and benefits in life cycle costing. Management of Environment Quality, 16(2), 107-118.

Sumida Group. (2012). Guideline for Green Procurement, July, Sumida Corporation.

Swarr, T. \& Hunkeler, D. (2008). Life cycle costing in life cycle management. In Hunkeler, D., Lichtenvort, K., \& Rebitzer, G. (eds.) Environmental life cycle costing. Boca Raton: CRS Press. (pp. 77-90).

Tanaka, M. (1985). New approach to the function evaluation system in value engineering. International Journal of Production Research, 23(4), 625-638.

Tanaka, M. (1995). Theory and practices of cost design. Tokyo: Chuo Keizai Publisher.

Tanaka, M. (2002). Profit strategy and value engineering: how to implement practical cost design. Tokyo: Noritu University Publisher.

Tanaka, T. (1992). Field study: contemporary management accounting system. Tokyo: Chuo-Keizai Publisher.

Tanaka, T. (1993). Target costing at Toyota. Journal of Cost Management, Spring, 7(1), 4-11.

Tani, T. (1994). Interactive control in cost design: significance. The Kokumin-Keizai Zasshi (Journal of National Economy), Kobe University, 169(4), 19-38.

Tani, T. (1995). Interactive control in target cost management. Management Accounting Research, 6, 399414.

Tani, T., Okano, H., Shimizu, N., Iwabuch, Y., Fukuda, J., \& Cooray, S. (1994). Target costing management in Japanese companies: current state of the art. Management Accounting Research, 5, 67-81.

The Nikkei. (2014). Recall of 1.9 million hybrid cars in Toyota in Japan and abroad, Feb. 12, Nihon Keizai Shinbun (Japan Economy Newspaper) Inc. http://www.nikkei.com/article/DGXNASDG1203y_ SaA210CR8000/. Accessed 22 February 2014.

Thun, J., \& Hoenig, D. (2011). An empirical analysis of supply chain risk management in the German automotive industry. International Journal of Production Economics, 131, 242-249.

Toshiba Group. (2013). 2013 Environmental report. http://www.toshiba.com/csr/docs/env_report13_all. pdf. Accessed 10 June 2014.

Toyota Motor Corporation. (2011). Toyota Green Purchasing Guidelines, December.

Toyota Motor Corporation. (2013). Report for the planet: Toyota'senvironmental initiatives (pp. 22-23).

Yamamoto, K. \& Kokubu, K. (2001). Environmental management in IBM: Toyo Keizai Inc.

Yoshida, E., Fukushima, K., \& Senoo, T. (2012). Studies of Japanese management accounting, Chuo Keizaisha.

Yoshikawa, T. (1994). Some aspects of the Japanese approach to management accounting. Management Accounting Research, 5, 279-287. 